\title{
Sport and Art: Differences and Theatrical Similarities
}

Authors' contribution:

F) conception and design of the study

G) acquisition of data

$\mathrm{H})$ analysis and interpretation of data

I) manuscript preparation

J) obtaining funding

\section{Jerzy Kosiewicz}

Josef Pilsudski University of Physical Education in Warsaw, Poland

KEYWORDS

\begin{abstract}
A certain tradition of philosophical considerations on the interrelation between sport and art has already been established. According to Tim L. Elcombe (Elcombe, 2012, p. 201), such considerations on the subject first appeared in English-language literature in the 1970s and 1980s, and were fruitful. Usually, they appear together with questions on the aesthetic properties of sport - in this case, a special issue of the Journal of the Philosophy of Sport dedicated to "Sport and Aesthetics" (2012, vol. 39, no. 2), and an excellent postdoctoral dissertation by Jakub Mosz entitled "Estetyczne aspekty uczestnictwa w sporcie" (English: Aesthetic aspects of participation in sports) may serve as good examples. In his article (Elcombe, 2012), Tim L. Elcombe describes the contention and briefly characterizes the main differences between the two opposing viewpoints (Elcombe, 2012, pp. 202-204). It should be noted that he sympathizes with the view of David Best, who some years ago argued that sport is not art (1988, pp. 527-539). He believes that "although art could use sport as a subject, art could not be the subject of sport" (Elcombe, 2012, p. 202). I would like to make that statement more specific by adding that its second part suggests that the display of artistic values cannot be the fundamental purpose of sport. I shall expand on that later.

Best's viewpoint was criticized by Jan Boxil (1988), Spencer Wertz (1988), and Terry Roberts (1995), who believed that sport could be treated as art. Christopher Cordner (1995a; 1995b) and Joseph Kupfer (1988) also challenged Best, although they did not entirely disagree with him (see: Elcombe, 2012, pp. 202-204).

Because literature on the subject published in English presents diversified statements on the interrelation between sport and art, and the circle of people engaged in the matters of physical culture in Poland is still in favor of equating sport with art, I have decided to present my own stance on that matter.

sport, art, applied art, athlete's activity, sport athletics spectacle, theatre performance, aesthetics of ugliness
\end{abstract}

\section{Hypotheses and assumptions}

In the subsequent statement on interrelations between sport and art, I have considered three hypotheses and one assumption. The hypotheses are as follows:

1. Sport and art constitute two separate and distinct spheres of cultural activity. Equating one with the other is a mistake that leads to misunderstandings. 
2. Considerations on the effects of both sport and artistic activity indicate that between - just as within the range of terms used to discuss them - the two occurs approximation, interpenetration, and intersection.

3. The research pertaining to the approximation, inter-penetration and intersection of sport and art understood as concepts and phenomena proves that they constitute two distinct and separately defined spheres of knowledge, which confirms the first hypothesis.

The proposed assumption is, in turn, that the questions of the effects of activity in sport and art examined here will only take into consideration authentic artists and athletes competing at high levels. When it comes to both art and sport, the activities of amateurs will not be analyzed herein. It should be noted that an amateur who achieves a confirmed level of artistic skill ceases to be a dilettante and becomes an artist appreciated to varying degrees, like in the case of Nikifor, the Polish naïve painter. The same happens when a sportsperson converts from an amateur to a professional athlete aspiring to considerable success.

In art, to pinpoint what confirms one's status as an artist is more difficult than in sport, where for the most part measurable criteria are used. This is so because the confirmation of an artist's status is - aside from the substantive and formal diplomas and certificates, as it is in the case of artistic schools or extramural exams - of a discretionary nature. For instance, Expressionism and Impressionism were not originally regarded as art, and the painters representing them were not considered artists. In his lifetime Vincent van Gogh was an unnoticed painter; he did not generate any interest. He was not regarded as an artist.

\section{Sport and art: An attempt at defining characteristics}

It can be acknowledged, both in connection with and irrespective of the existing definitions of sport, that that the principal characteristic of sport is the pursuit of goals of praxeological (pragmatic, utilitarian, and practical) nature, connected with rivalry of immediate kind (during competitions) and intermediate (correspondent) kind, based on the comparison of results achieved in different place and time.

I should note that I see the praxeology of sport as the part of practical science (that is, praxeology), which looks at the efficient and effective ways of achieving optimum goals set in competitive (professional, spectator, and Olympic) sport (see Kotarbiński, 1982).

The most important goal in the kind of sport indicated is the achievement of the best possible result, the highest place in a given match, game or competition or a more broadly planned rivalry. The more appreciated the prospective achievement is, the easier it is to reach other goals, that is, the additional, implicational goals of, say, prestigious, financial, political, national, public, ideological, moral, environmental (peer, family), cultural and civilizational (from country to city), or touristic (attractive sports trips) significance.

The assessment is based either on measurable (objective and universal) or measurable-discretionary criteria (based on the commonly applied criteria for evaluation set in rulebooks for different sports disciplines). The results of assessment form the basis for a ranking made immediately after a competition as well as in a scheduled cycle of competitions.

It should be noted that the basis of sports rivalry is the game, understood as acting according to predetermined rules, rulebooks or regulations, adherence to which is necessary in the restrictive sense, and is also a condition that enables the achievement of goals set in sport. At the heart of the game, in turn, lies the play in its primary, initial sense, which is the rivalry connected with fun and entertainment - its ludic aspect that brings joy, satisfaction from physical activity and fitness that may be of changing nature, e.g., cathartic, escapist, hedonistic, aesthetic, pro-health or epistemological, or rather epistemic: connected with, among other things, non-research experience and study of close and distant places at home and abroad.

In sport, especially in its highly (that is, optimally) qualifiable form, the body and its maximum or super-maximum exertion, as well as the almost supernatural effort of will, emotion, cognition and relation of 
the athlete (who needs to adapt to others in a team), are of a strictly objective, instrumental or implicational character and constitute means for achieving the optimizational goals set in sporting rivalry ${ }^{1}$.

\begin{abstract}
${ }^{1}$ In the main text the notion of sport is discussed in an abbreviated way in order to adjust it to the central thought, to the content of the argument. In literature on the subject there are many more interpretations. For example, I can quote a description characteristic for sport social sciences, which is presented by D. Malcolm (2008, pp. 238 - 239) referring to A. Guttmann (2004), B.D. McPherson (1989) and N. Elias and E. Dunning (1986). He proclaims that it is common practice for the term "sport" to be used interchangeably with the terms play and game, whereas he is of the opinion that these are different notions, in spite of the fact that attempts at defining sport usually refer it qualities to the abovementioned terms. Malcolm writes - referring to Guttmann - that the most general from among the non-utilitarian forms of activity of physical and mental character is the category of play. It has strictly autotelic - and not instrumental - qualities. It refers neither to health-oriented aims, nor to personal development, nor to physical or mental fitness, nor to earning for a living. It results from that, for example, that school and extra-school physical education or professional sport are not forms of play.
\end{abstract}

Play - as Malcolm proclaims after Guttmann - can come into existence in a spontaneous or an organized way. If play has organized character, we are dealing with a game. A game can be based on competition (competitive game) or take place without it (non-competitive game). The term refers to various activities - competition (like popular polevault competitions), fight, contest, strictly physical rivalry (like in contact- and non-contact sports) and intellectual rivalry (I would like to add that it can also have mixed character).

However Malcolm, who presents Guttmann's views, is of the opinion that, in spite of the fact that indubitably there is an intellectual component in sport, its character is determined by physical effort, which is immanently integrated into its structure (except of chess and bridge as a sport) and which is based on specific bodily fitness and developed skills. However, the abovementioned rivalry - in contrast to real fight or war - is based on playful game. It takes place in a joyful way. It has also qualities which are characteristic for play - autotelic values.

Guttmann creates a very general and, simultaneously, one-sided definition of sport, which passes over traits of highly qualified, highly competitive, professional, Olympic or spectacular sport. He proclaims that sport can be defined as an activity including competition, fight or contest of organized character, rivalry including elements of joyful game and play of non-utilitarian character, where physical competences (conditions) took precedence over intellectual ones ("sports can be defined as organized contests of a playful, non-utilitarian character in which the physical demands outweigh the intellectual components" (Malcolm 2008, p. 238).

That definition comes from 1978, from the first edition of Guttmann's book. It is probably the reason why sport was saturated there with autotelic qualities characteristic for the then and earlier times, for Coubertin and his followers. They negated professional sport treated in a utilitarian, instrumental way - that is, as a means for other non-sport aims.

Malcolm presents also McPherson and his co-authors' interpretation of sport. They distinguish the four most important qualities in it. A significant criterion enabling the evaluation of how advanced a given sport is and what its level of competences and its level of structuration are. A proper structure (formal assumptions) is significant for sport even in its informal forms. It is necessary, for example, for children's street or backyard football, or for playing baseball in a park. In those and in other cases the course of the game is determined by some rules which are known and accepted by its participants. That type of sport has a low level of formal structure. A higher level of structuration is characteristic, for example, for the Football World Cup. Its preparation and course are strictly controlled by great bureaucratic sport and non-sporting institutions, which are established, among other thingss, to do that on the basis of rigorous rules which have been accepted earlier.

The second significant quality of sport is the fact that it is goal-oriented on variously understood success. It depends on criteria which - similarly to the criteria for failure - are usually clearly defined.

The third characteristic feature of sport is rivalry between particular athletes or teams, whereas the fourth quality is, in their opinion, its ludic character. They maintain that sport is ludic, which implies - according to them - that sport includes also qualities characteristic for play and game. They justify it in an etymological way, because the term "ludic" comes from the Latin "ludus", which means play or game. Summing up, it can be proclaimed that sport, according to McPherson and his co-authors, is a structured, competitive form of game, which is teleologically oriented on success.

In the abovementioned definitions it is possible to notice cultural messages which are implicitly rooted in them. It is confirmed by N. Elias and E. Dunning (1986), who point out that contemporary sport refers to patterns of competitive physical activities, which appeared in Britain and Ireland in the $17^{\text {th }}$ and the $18^{\text {th }}$ centuries. It is also possible to point to different understanding of similarities and differences between play, game and sport. For example, G. Tomc discusses these notions referring to B. Suits and K.V. Meier's viewpoint and presenting - in opposition to them - his own understanding of these terms. He proclaims that "For Bernard Suits, sport may or may not be play (if it is involuntary or extrinsically motivated, it is in his opinion not play) may or may not be game (he distinguishes sport games in which rules are the crux of the matter, like soccer; from sport performances, in which ideals are essential and to be approximated, like gymnastics). For Klaus V. Meier sports may or may not be play (as in Suits) but are 
Thus defined, sport significantly differs from art because the fundamental objective of art as well as the ambition of an artist are the attainment of the objective itself, the autotelic aim, the aim that represents the highest value. Artistic values are what constitute this superior aim. They are discretionary, relational, relative properties as well as those relating to the accepted or the diverse and changeable properties initiated in opposition to the existing, undermined or, possibly, receding aesthetic-artistic paradigm. The artistic choices are in this case strictly correlative to the artistic effect.

The above definitions of sport and art, very concise and strictly utilitarian (suited to the topic of this paper) point above all else to the existence of a substantial axiological and teleological difference between sport and art, which at the same time does not disqualify other viewpoints.

The kind of sport in question - competitive, professional, spectator, Olympic and highly qualified sport - has, above all, instrumental and reifying properties and constitutes means for achieving the main aim, namely, the best result in a related competition, as well as the secondary, implicational aims of diverse social overtones. It is instrumental in itself and objectifies man in pursuit of a goal.

Incidentally, there is nothing wrong (except in the case of aberrations, deviations, or pathologies) in the kind of sport in question leading to the objectification of the subject, to the reification of the athlete, since this is what characterizes almost all types of work that provide a livelihood to man and his immediate environment (e.g., his family). In his master-slave dialectic presented in Phenomenology of Spirit, Hegel insists that it is work that constitutes the source of the essential ontogenetic - and phylogenetically enmeshed - development of a self-conscious being. It is also the condition enabling one to overcome stagnation and, possibly, the servile submission to the interest of others (Hegel, 1963, pp. 216-218).

Art - as opposed to the forms of sport discussed here - pursues above all else the autotelic aim, which in this case is strictly (in a crucial sense!) artistic. On the other hand, all the remaining goals connected with art are at the very most secondary. This applies to the subject areas presented in works of art, be it politics, Soviet labor camps, nature or sport. For instance, the cognitive goal connected with them - regardless of its prominence or extent of exposure - is still secondary in character to the artistic goals. If a literary work, for example, was chiefly to expose the facts about, say, the subjects just mentioned, we would be dealing with a

necessarily games (they require physical skill by participants pursuing the goal of the game), although all games are not sports (for example chess or poker)" (Tomc 2008, p. 9).

Then Tomc - considering qualities of play, game and sport, and then relations between them, taking into account performances, rituals and experimentaion, comes to the conclusion that there are:

“- games (in which parallel world of pretence is created by players trying to approximate an ideal skill, for example a physical skill in sport),

- performances (in which a parallel word of pretence is created by players trying to approximate an ideal representation of life, for example an aesthetical production),

- rituals (in which a parallel world of pretence is created by players trying to approximate ideal behavior for example an aesthetical production) and

- experimentation (in which a parallel world of pretence is created by players trying to approximate ideal classification of the world, for example scientific research.

- It follows from our theoretical perspective that

- all sports are either games or performances,

- all games and performances are not sport,

- $\quad$ but all games and performances are forms of playing" (Tomc, 2008, p. 9).

I present two quotations - and not their discussion - because Tomc presents Suits and Meier's viewpoints - as well as his own - in a highly essential way. Hence their synthetic interpretation could deform their content. What is significant in that case are also original expressions. By the way, such a type of formal solution is permissible also in notes or stage directions constituting marginal currents of considerations in their relation towards the central statement.

Treating Tomc's considerations as the context for an analysis of S.R. Kretchmar's views included in the paper presented during the conference of the International Assotiation for the Philosophy of Sport in Seattle (August 2009), entitled "Do Games Require Artificial Problems That are Neither Too Hard Nor Too Easy?", it is possible to notice that reservations about Suits' conception presented by the outstanding Slovenian sociologist can be referred - to some degree - to the paper of the American philosopher of sport. 
more or less successful treatise on politics, Soviet labor camps, nature or sport, and not with the art of literature. In the case of cinema, the result would be a documentary instead of a feature film.

Engagement in art is not connected with adherence to the rules of any sports discipline, nor is it based on either the principles of the game or the rules and values identified with the play. Every artistic discipline is characterized by specific tendencies, schools or trends, such as Classicism, Mannerism, Rococo, Expressionism, Impressionism, realism, socialist realism, and neo-realism, and counter-tendencies presaging more or less radical changes, including revolutions in arts and aesthetics.

\section{Applied art and sport}

It is assumed that the narrowly defined term "applied art" refers to those facts, phenomena, and (most notably) objects that serve to facilitate everyday activities and at the same time make them more enjoyable. While the use of such objects is helpful in identifying and satisfying human needs, their usage can also, apart from being a source of artistic-aesthetic experiences, provide various practical benefits. This refers to objects such as luxury watches, items of jewelry, powder boxes, and architectural designs (for instance, the buildings in Barcelona - including the Sagrada Familia - designed by the modernist-secesionist architect Antonio Gaudi).

A utilitarian purpose may provide an excuse to create an object of applied art. When such an object has significant aesthetic-artistic value, it becomes reserved for protected private or public exposition, just like famous paintings, engravings, or sculptures. However, when its utilitarian value is greater than its artistic quality or the aesthetic concept behind it, a ring or a powder box will find its way only to a lady's bag or onto her wrist. Such objects are usually pretty, sometimes beautifully crafted and richly ornamented, yet they do not display any serious artistic qualities that would considerably increase their market value.

While discussing such matters, it worth reflecting on what makes a given object that represents the discussed art form (which in this case is applied art) a work of art and not simply an aesthetic phenomenon; what makes it evoke an artistic experience instead of a merely aesthetic experience. Does it come from its source (functional) purpose or from the kind of emotional response that it evokes - the aesthetic-artistic experience independent of its pre-established practical purpose? In this case, it is not so much the experience of practical usefulness as the perception of its (after all, distinct) autotelic values that evokes the aestheticartistic experience. A functional object only becomes a work of art because of its aesthetic-artistic values, not because it serves to measure time, secure valuables, or store cheap face powder.

Thus, while a project that allows for the functional purpose of an object can be a source of artistic inspiration, the deciding factor or whether its realization will actually become an object of art is the work and talent of a particular goldsmith or watchmaker. However, the artistic effect does not depend as much on the planned ornaments as on their actual quality in the finished object. The sole endeavor, the act of making the object, and the completion of the project do not determine its artistic value. Instead, it is determined by what Plato called divine inspiration, the frenzy or madness of divine provenance ${ }^{2}$. If this gift, as understood by

\footnotetext{
${ }^{2}$ It is possible to conclude from the context of Plato's views that the discussed culture-creative influences have direct and purposeful character. They enable to realise the need of immortality in the cultural (and civilisational) dimension thanks to activity which is going to be appreciated by future generations. It refers to, among others, creative activity of philosophical (scientific), artistic, artisan, architectonic, political, economic, religious or sports character. Great philosophical and mathematical works, astronomical discoveries, excellent dramas, poetry, eposes or great edifices - ancient palaces, temples or theatres - brought their creators a kind of a longer or a shorter (from the current viewpoint) immortality for the period of lifetime of generations. It refers also to effects of activity of distinguished statesmen, political and economical solutions contributing to development and splendour of various societies. An important place in universal history is occupied by religious leaders as well as brilliant military strategists and excellent Olympic winners (sportsmen or artists).

Plato created a conception of divinely inspired culture. He raised the status of all manifestations of culture presenting them as coming into existence because of inspiration of the Eros absolute. They contain - as it may be supposed - noble aspiration for divine perfection; that is, to Plato's ideal of culture as such (which contain, in the range of its notion, its peculiar manifestations, which are called - not only nowadays - civilization); and to its particular components in the form of various ideals of a smaller range, such as, for example, poetry, sculpture, painting, faith, moral codes, agriculture and military craft,
} 
sailing or trade. Particular elements of culture - and creative experiences which are connected with it - prove that Eros, who distinguishes a given man and stigmatizes him (as well as the effect of that man's work of autotelic and instrumental qualities) with his divine beauty, is favourably disposed. That stigma, a manifestation of Eros' stigmatization, can be identified with the author's talent - that is, with its objectivised abilities providing with social recognition and memory passed down from a generation to a generation, what is a realization of a relatively understood immortality.

Awards and fame come as a confirmation and evidence of unique talent, which is borne under such influences

as:

a) an inspiration, or divinatory or prophetic madness sent - according to Plato (Plato, 2012, pp. 230-231 and $251)$ - by Apollo. In this case, Plato makes a reference to Socrates' second speech and Socrates' subsequent remark on madness, which, contrary to the one "produced by human illness" (Plato, 2012, p. 251), is produced by "a divinely inspired release from normally accepted behavior" (Plato, 2012, p. 251).

Plato - in his Symposium - also attributes divinatory madness to Eros. In this case, he makes a reference to the argument presented by prophetess Diotima, a “woman of Mantinea” (Plato, 2012, p. 185), who believes that Eros' work is "giving birth in beauty, whether in body or in soul" (Plato, 2012, pp. 190). She also counts him among the:

"messengers who shuttle back and forth between [god and mortal], conveying prayer and sacrifice from men to gods, while to men they bring commands from the gods and gifts in return for sacrifices. Being in the middle of the two, they round out the whole and bind fast the all to all. Through them all divination passes, through them the art of priests in sacrifice and ritual, in enchantment, prophecy, and sorcery. Gods do not mix with men; they mingle and converse with us through spirits instead, whether we are awake or asleep" (Plato, 2012, p. 187).

b) Dionysius-inspired religious madness (Plato, 2012, pp. 230-231 and 251), "inspiration (...) of the mystic" (Plato, 2012, p. 251), which initiates or arouses deeper religious needs, stimulates the pursuit of further initiations, provides access to the highest divine arcana (Kosiewicz, 2013, unpublished). It gives, says Plato:

"prophecies and takes refuge in prayers to the gods and in worship, discovering mystic rites and purifications that bring the man it touches through to safety for this and all time to come. So it is that the right sort of madness finds relief from present hardships for a man it has possessed" (Plato, 2012, pp. 230-231).

c) creative inspiration induced by the Muses (Plato, 2012, p. 251). In his discussion of the four kinds of madness as presented in Socrates' second speech, Plato says that:

"Third comes the kind of madness that is possession by the Muses, which takes a tender virgin soul and awakens it to a Bacchic frenzy of songs and poetry that glorifies the achievements of the past and teaches them to future generations" (Plato, 2012, p. 231).

This type of both creative and artistic work is inspired not only by the Muses, but also by the mysteries and carnivalesque processions, pageants, and other forms of worship of Bacchus. For example, winning theatrical (drama) competitions dedicated to Dionysus brought the winners awards and fame of both artistic and religious nature. Such competition was in fact an evidence of both religious worship and soteriological motivation. Similarly, during the Panhellenic games, athletes aspired to provide a proof of their ability to outperform other competitors in a specific form of cult, a proof of the precedence of their title to divine honors and salvation over the others. A pursuit of glory and honor, immortality and memorability, is clearly a noble and laudable phenomenon in this context.

d) love madness inspired by Aphrodite and Eros, which causes human beings to seek specific immortality (in the Platonic understanding), not only through procreation, but also through different forms of activity in such fields as art, agriculture, economy, politics, and warfare. This includes philosophical activity, which, according to Diotima, is inspired by Eros, the patron of philosophers, whom she also counts among these. Eros seeks knowledge and wisdom (N.B., these being two concepts that would be treated as analogues until Aristotle's times) (Kosiewicz, 2013, unpublished). She says that Eros (Love) "is in love with what is beautiful, and wisdom is extremely beautiful. It follows that Love must be a lover of wisdom" (Plato, 2012, p. 188). His goal, in turn, is "giving birth in beauty, whether in body or in soul" (ibid, p. 190).

In Socrates' second speech, Plato also argues that creative madness is not "something to be ashamed of or worthy of blame (Plato, 2012, p. 230), that it is always "given as the gift of the god" (Plato, 2012, p. 230), and he concludes his argument on "some of the fine achievements (...) that are due to god-sent madness" (Plato, 2012, p. 231) by stating that "this sort of madness is given us by the gods to ensure our greatest good fortune" (ibid). He further argues that should anyone come to the gates of art or any other illustrious and memorable creative activity and expect, say:

"to become an adequate poet by acquiring expert knowledge of the subject without the Muses' madness, he will fail, and his self-controlled verses will be eclipsed by the poetry of men who have been driven out of their minds" (Plato, 2012, p. 231).

In this respect, he acknowledges that:

"madness (mania) from a god is finer than self-control of human origin, according to the testimony of the ancient language givers" (Plato, 2012, p. 230).

"We must not have any fear on this particular point, then", adds Plato with regard to madness, "and we must not let anyone disturb us or frighten us with the claim that you should prefer a friend who is in control of himself to one who is disturbed" (Plato, 2012, p. 231). 
Plato, is not present (is not materialized), the objects created (regardless of their beauty) are not examples of art but of broadly understood craftsmanship.

It should be noted that craftsmanship, just as rhythmic gymnastics, is in no way connected with art. While the aesthetic aspect is emphasized in both craftsmanship and rhythmic gymnastics, they are not representative of artistry characteristic of fine arts per se (particular, clearly defined, and established art forms). The aestheticization dependent on the divine spark or divine inspiration is what enables the creation of works of art, including the works of applied art. Beautiful things, such as dresses from leading fashion designers (in Polish unduly called "fashion creators") or persistently refined landscapes that depict red deer during rutting season, may be created and still not earn the right to be called art because they do not have artistic value. Divine inspiration, not possible to pinpoint or define, initiates immortal works and decides whether one is merely a versifier or a true poet, an unremarkable painter (regardless of skill and practice) or an artist immortalized in his work, a bad or a good philosopher, a minor fortune-teller or a true prophet ${ }^{3}$.

Other sources of creative inspiration - such as contests or commissions - are secondary and have only motivational, stimulating significance. They do not decide on the future value of a work of art. Its artistic significance is shaped by the divine spark, the transcendental impulses of which, according to Plato, the author himself is unaware.

Wiesław Myśliwski - through the character in his novel Ostatnie rozdanie (The Final Draw) - also speaks about this lack of awareness: "Oh (says a nude art model to the author of the drawing), look at that thick line which seems to protect my breasts. You may not even be aware of that. Art doesn't need to be aware of itself" (Myśliwski, 2013, p. 96).

I believe that Stanisław Myśliwski equates art not only with manifestations of beauty but also with artistry and the artist. The artist does not need to be fully aware of the value of art he has created nor does he to comprehend everything that it expresses even if he created it; inspiration comes from beyond the artist and transcends him. Creative frenzy subsides, and art remains ${ }^{4}$.

Clearly, what he means by being disturbed is to yield to a divine spark, to supernatural inspiration that may produce outstanding works, leading to immortality or (merely!) memorability.

It should be noted that I have spoken many times about Plato's concept of beauty, aesthetics, and art, as well as other forms of creativity inspired by the divine spark, during conferences organized in Greece by the International Association of Greek Philosophy. I have also written on the aforementioned topics in the papers, which will be published by the Association. This regards:

Kosiewicz, J. (2014). Philosophy in the Crucible of Etymology: Madness and Cognition;

Kosiewicz, J. (2014). The Body, Sex and Erotic Love in the Context of Plato's Philosophy of Culture; Kosiewicz, J. (2014). Religious and Philosophical Determinants of Pythagoreanism.

${ }^{3}$ It should be noted that prophesying is seen by Plato and Diotima of Mantinea as divine madness and is contrasted with fortune telling, seen as a merely technical skill, devoid of frenzied metaphysical inspiration

${ }^{4}$ Wiesław Myśliwski presents a refined disquisition on art that implicitly characterizes the manifestations of elusive artistry in a touching and perceptive way, in the form of a dialog about a nude painting. He does not write volubly on beauty or aestheticization but instead talks about art which seems to grasp something beyond reality and its persistent aestheticization, mistakenly treated as a manifestation of art. He writes about a model posing for a nude in a college studio:

"I was trying to look at her not so much with my eyes as with my imagination. The more so as I had no confidence in nudes whatsoever. The helplessness of a nude seemed to subjugate my imagination, forcing it into the established canons. I felt as helpless in the presence of all the nudes I had seen at art galleries or exhibitions, or their reproductions in albums, as she did in my presence. Looking at a nude I had a feeling that its pictorial nature made it somewhat unable to match anything but the bareness of a body. It did not reach the anxiety, the fear or the pain hidden beneath the coat of any nudity (...) At least that was what I thought at that time.

I had been thinking for a long time before I started to sketch. Still, nothing was working out. I tore down a couple of sketching sheets. Especially that the longer I looked at her, rearranging her position, stretching out on the sofa, restless, fickle, for how long can one lie motionless, the more I felt that she was regaining confidence in her body. And it was as if she wanted to control every thinnest line of our yet unfinished sketches, not allowing for the slightest divergence from her own vision of herself; in any case, not letting the eyes wander beyond her notions of herself.

At some point I even suspected that maybe my thoughts could reach her and she was trying to meet the demands of a nude, trying to prompt me to draw her the way she wanted to be drawn. And there, I had the idea to capture her in 
An author of a novel or a theater play, or a philosopher may - having studied the ideas of Plato - come to realize (just as the famous Athenian did) that they bear the imprint of divine inspiration. This, however, is not always the case. Many authors wrote for their own pleasure and others, even if they published or exhibited their works, were only appreciated posthumously (this group includes David Hume and Vincent van Gogh). Wisdom and art, both the effect of human activity, do not have to be aware of themselves. One inspired by madness does not need to delve into what is the actual source of their inspiration.

I believe that Plato did not distinguish between artistry and beauty. He considered wisdom, knowledge, love, good, and justice to be beautiful even though it is hard to ascribe any artistic values to them. He also identified aesthetics, which is, for instance, the beauty of poetry or drama with artistry. In contrast to Aristotle, Plato believed that eminent works of art are not manifestations of mimetic activity, of arduous craftsmanship but instead are manifestations of beauty, of a far-reaching approximation directed towards the idea (and ideal) of beauty. The measure of artistry both back then and now has been the potential immortality of a work of art and an artist. The greater the potential, the greater the artistry ${ }^{5}$.

It should also be noted that Plato did not differentiate between the immortality of outstanding works (artistic and non-artistic) and their time-related significance. For not all accomplishments - including artistic attainments - stand the test of time. The novels of Stanisław Przybyszewski, for instance, much sought-after during the Young Poland period and highly appreciated by European Modernist bohemians of the late nineteenth and early twentieth centuries, ceased to be treated as noteworthy prose after just several dozen years - she was deemed a mere scribbler. Przybyszewski did not manage to achieve the eternal fame that was predicted for her - in fact, her output could not secure such significance for her even for a single century.

The universalist and objectivist tenets found at the heart of all eminent works characterized by Plato in the second speech of Socrates and a subsequent passage of Phaedrus (Plato, 1993, pp. 28-29 and p. 57) do not consider the discretionary, relational and relative nature of values as well as the changeability of criteria for works of art. Plato believed that if poets, singers (for instance, Homeridean plebeian singers), dramatists

few strokes of charcoal, reclaiming her from that banality characteristic of every body. Her transparent skeleton, like in an x-ray picture, forced itself on me, the body a mere mist, a memory. I abandoned that design, however, as she looked at me sharply and I caught a glimpse of terror in her eyes. But I didn't want to hurt her; I just wanted to integrate mortality and immortality, lust and evanescence, disintegration and oneness in her naked body. In that glimpse of terror she seemed to plead with me to perceive her as something more than just a posing body" (Myśliwski, 2013, pp. 90-91).

After a confrontation with the head of the Department of Drawing the narrator tore up his drawing in four, and proceeded to relate the model's reaction to the incident:

"I picked up the pieces of the drawing from the floor when you were running out of the room (...) and arranged them like that. The longer I looked at it, the more I vacillated between enchantment and terror at my own image. It was not about me being like or unlike myself in that picture. Please, do not suspect me of such expectations. Art does not look for any similarities, and you know it well yourself. Art is not dependent on anything: landscapes, objects, or even man. Only a simpleton can believe that they imitate, recreate or transfer something from the world that surrounds them and onto a sketch or painting (ibid, p. 94).

“Oh, look at that thick line which seems to protect my breasts. You may not even be aware of that. Art doesn't need to be aware of itself" (ibid, p. 96).

"I might not even have paid attention to that drawing of yours if you hadn't torn it. I thought that maybe you have touched something within me that I don't know of. And the pain shoot through me. I truly don't know how to describe that feeling" (ibid, p. 95).

${ }^{5}$ Kevin Ayote, referring to Diotima's statement included in "Symposium", proclaims that beauty and love, that the real knowledge of beauty itself - that is, philosophical reflection on beauty - is, as a consequence, a true virtue making it possible to find deathlessness (Ayote, 2001, p. 34). Robert Mitchell - referring to Diotima - points out that someone who climbs the ladder of beauty making the highest values "that is one, above all men, who is loved by the gods and is deathless" (Mitchell, 1993, p. 168). He is a being who, regarding his body, is an earthly and temporal phenomenon (that is, he appears and disappears), but who can, nevertheless, participate in eternity regarding the fact that he is "spiritual in nature"

(Ayote, 2001, s. 34). He explains, after Diotima "how the body and all else that is temporal partakes of the eternal" (ibid.). 
and sculptors were under the influence of divine inspiration, if they created when moved by supernatural frenzy, then they were making manifest in their art the ideal beauty that could not be undermined by anybody at any point in history. That perfect beauty could have been, and in fact was, equated with most sublime artistry, although Plato did not use the term.

Regardless of Plato's views, works of art can undergo changeable evaluation: they can be degraded or elevated according to their decreasing or increasing market value that influences their sales appeal and attracts wealthy art collectors and famous museums.

Art is discretionary and subject to trends. For instance, even though Friedrich Nietzsche declared Carmen (to annoy Richard Wagner) the greatest opera of all time, its premiere was a complete fiasco. Władimir Nabokov, in turn, had importuned countless publishing houses to print his Lolita before he finally succeeded. Initially, many literary experts employed at editorial offices regarded the novel as kitsch and rejected it as a clear example of talentless writing.

Sport, however, is in most cases beyond discretionary criteria - this applies mostly to measurable achievements and disciplines, as well as to immediate rivalry. Performance at different athletic events, for instance, can always be compared and contrasted. The sprint and long jump results obtained by James Cleveland (Jesse) Owens at the 1936 Summer Olympics in Berlin will always be deserving of credit.

As for the concept of the broadly understood term "applied art" (and such perspective is a permissible one), it can be said that every form of art, every artistic object has one or more past, present or future users. Therefore, art does not only pursue autotelic aims, but it also possesses instrumental qualities, as it addresses the needs, expectations and desires of people interested in different forms of art. And artists take that into consideration, the divine impulse notwithstanding. From the Renaissance or court painters, through writers that served Social Realism, to filmmakers and architects, artists have depended on patronage to a certain degree - be it financial, religious, political, or ideological.

All art forms are created with a particular audience in mind: the various genres of novels (from crime stories and romance novels to adventure and fantasy stories for children); films, TV series; theater performances (both the classical, academic, traditionally staged productions and the ones performed in an alternative space - based on an unrestricted and avant-garde treatment of classical tragedies, comedies and tragicomedies); different types of paintings - marine paintings, battlefield paintings, portraits, etc. Every genre of painting or sculpture has its enthusiasts and they are the primary addressees of a given artistic fact. This is also true for architecture, interior decoration and furniture from different periods (such as the reign of Louis XVI or art nouveau). Essentially, all art is applied: it is intended for a specific audience that seeks not random but specific, predefined aesthetic-artistic experiences.

Memorable achievements in sport are, according to Plato, the effect of creative frenzy or the divine spark; the same can be applied to significant religious, philosophical, political, military, economic, legal, moral, aesthetic (artistic) accomplishments. However, sports achievements are not artistic achievements despite the fact that Plato chose to consider them from the perspective of beauty. The Panhellenic Games were above all a unique spectacle of sport and religion at which artistic rivalry was present alongside sports rivalry. Such was the case of the Dionysia, a biennial theater festival in Athens in honor of the god Dionysus. Still, sports rivalry in itself was not treated as a form of art back then, and is not regarded as such today. Moreover, sport is not a manifestation of any form of applied art in its narrower definition presented herein.

\section{Sport and art: Mutual influence and inter-fusion?}

Let us first consider art. Can the fact that sport is present in art as its subject or that art alludes to sport testify to sport - as understood within this paper - also being a form of strictly artistic activity?

The answer is: Certainly not.

Sport inspires various art forms, such as literature (prose, poetry, drama), theater, film, painting, sculpture, architecture, and song. However, sport is not as significant or powerful a source of artistic 
inspiration as love, war, or family relationships. Nevertheless, that is not of essence. The crux of the matter is that these sources of inspiration, just like sport, are not in themselves artistic facts.

The value of artistry does not belong to any object, fact, or act independent of human activity and consciousness. Only man can create objects of art and artistic occasions and all related aesthetic concepts. The fact that there exists the aesthetics of reality (Golaszewska, 1984), for instance, the beauty or unattractiveness of nature, does not prove that nature itself could, in some special circumstances, become an artistic fact. It can only inspire various artistic statements and new, distinct aesthetic concepts. It is assumed - independently, that is, in opposition to the universalist and objectivist tenets of Plato's metaphysics - that the aesthetic values ascribed to nature are of (in the source sense) subjective and relational (as well as situational and relative) character, which means that they depend on given subjects, interpersonal relationships, as well as individual and social assumptions and criteria.

\section{Do the acquired skills and the results of an athlete's activity prove that he is an artist?}

Whether an athlete may be called a sportsman or an artist is determined primarily by the purpose of their athletic activity. That purpose - as has been indicated above - encompasses above all praxeological, non-autotelic assumptions, requirements and values.

In certain forms of sports activity there appear - even strongly emphasized - aesthetic and artistic values. The former ones could refer to the aforementioned aesthetics of reality of strictly natural sort. They are also connected with the aesthetics of nature of a mixed, yet functionally consistent, natural-artificial kind, which can occur when the projects of sports facilities are made more tasteful so as to blend with the surrounding nature. This is true for facilities such as cross-country tracks for versatile horseback races, ski runs, and bodies of open water for water sports.

Certain disciplines show an internally consistent and fundamental connection of the praxeological qualities with aesthetic and almost or partially artistic (quasi-artistic) qualities that constitute their generic core. In such cases, there occurs a reciprocally stimulating association of those values and qualities, which boosts the chance of achieving the set goal of rivalry. This applies to disciplines in which sportspeople participate in very demanding activities or ballet practice including rhythmic gymnastics, synchronized swimming, figure skating, trampolining, diving, acrobatic gymnastics and dancesport participate in very demanding activities or ballet practice. Their rivalry is based on fine-spun movement sequences that make use of specialist skills and specific technical practice as well as of the aesthetic-artistic design. The aesthetic or artistic elements contained within the structure of the aforementioned sports are only instrumental and supportive, and are not goals in and of themselves. They are to be conducive to fulfilling praxeological premises. They serve to implement the more or less optimal teleological directive, the achievement of variously interpreted - success in rivalry ${ }^{6}$.

\footnotetext{
${ }^{6}$ Incidentally, Jakub Mosz called the sports disciplines mentioned in the text (such as acrobatic gymnastics, synchronized swimming, figure skating, trampolining, and diving) "aesthetic sports" in his postdoctoral dissertation. However, this is not a good name because it is based on common intuition and, as such, displays (from the perspective of aesthetics) features of colloquial and commonsensical thinking for several reasons:

a) Certain sports disciplines contain artistic elements originating from ballet, circus acrobatics or ballroom dancing, yet this does not mean that they are "artistic sports" in the strict sense - namely, that they are a form of art.

b) All sports competitions - spectacular to a lesser or greater extent - are saturated with various aesthetic values: they possess characteristics and elements connected with the aesthetics of everyday life, the aesthetics of reality, or the practical aesthetics. It does not authorize the conclusion indicating that all sports disciplines are "aesthetic sports".

c) The fragment I am directly referring to as well as the whole script of that postdoctoral dissertation suggest that Jakub Mosz sees aesthetics solely as beauty, as the very narrowly conceptualized philosophy of beauty, regarding entirely and exclusively beauty itself (Mosz, 2014, p. 122). Regrettably, such conceptualization is not professional and despite his philosophical background it is saturated with colloquial thinking. He regards certain disciplines as "aesthetic sports" due to the occurrence of beauty in various forms. They could be simply called "beautiful sports"
} 
The competitions here do not, however, bear any relation to artistic contests, for instance, ballet competitions, in which entirely different rules apply; such regulations, categories, and criteria are not found in sports.

Therefore, even athletes in the sports disciplines mentioned above are not defined strictly speaking as artists, as they do not represent any of the existing art forms. Any of them could be called "an artist," yet only in the colloquial sense. Then, "an artist" is a person who excels in a given sports discipline and has certificates or diplomas that confirm their sports achievements, not their artistic accomplishments or qualifications.

However, certain athletes give up sport for art. It can happen, for instance, in making human pyramids in acrobatic gymnastics. If acrobatic performances become part of stage shows, circus shows or variety entertainment, then they acquire - due to their placement within the artistic-aesthetic convention - the status of performing arts. In such cases, convention and type of the intended spectacle is what largely determines the choice of venue, the type of audience and emotional response. However, when acrobatics is a sport, it needs to adhere to sports regulations that specify the arena, the expectations of referees and supporters, as well as appropriate criteria for assessment (different than those for art).

It should be noted that nothing prevents universities interested in research and education in the field of physical culture to take up the study of interrelations of sport and art, and implement the outcome in the philosophy of sport curriculum. Vitor Melo of the Federal University of Rio de Janeiro Sport's Laboratory of the History of Sport and Leisure research center attempted to do just that with a team of 12 researchers. Their study specifies the following objectives:

a) To map out the artistic works where sport is part of the theme or represented;

b) To discuss the potentially observable intersemiotic dialogues between sport and different artistic manifestations;

c) To develop didactic and methodological strategies built from the dialogue between sport and different languages;

d) To discuss the sport representations in works of art (Melo et al., 2007, p. 337).

Considering the objectives above, it can be said that the authors neither claim nor suggest that sport and art are two areas of cultural activity characterized by con-generic or identical properties.

\section{On equating the work of a coach with that of an artist}

instead of "aesthetic sports." However (and unfortunately), it would bring to mind fine arts, although art does not need to connote the commonly, colloquially and commonsensically understood beauty.

d) Jakub Mosz entirely circumvents the branch of aesthetics that deals with ugliness: he does not consider the attributes of the aesthetics of ugliness. From the perspective of aesthetics and philosophy of art, ugliness constitutes a permanent and important component of a work of art. In such context, the name "aesthetic sports," which marks out certain sports and not other, seems to be substantively misconceived, since all sports rivalry, all sports spectacles contain both ugly and beautiful elements: they are all aesthetic.

A similar concept of an aesthetics that dismisses the consideration of ugliness in general and ugliness in sport (seen as a significant emotional factor that stimulates interest in sport) is represented by Teresa Olivera Lacerda (Lacerda, 2012, pp. 235-250). She sees aesthetics only as the philosophy and theory of beauty in its mainstream and colloquial conceptualization. It is that kind of beauty that she endeavors to discern in sport and to include in what she promotes as education for the aesthetics of sport in higher education in the sports sciences in Brazil and Portugal. In my opinion, the aesthetics of sport should constitute only an element of the philosophy of sport curriculum at universities. It should be noted that courses on the philosophy of sport (lectures, classes, and possibly seminars) may only be offered after courses on the history of philosophy, philosophical anthropology, or natural philosophy.

Inappropriate behavior, e.g., fouls - as Teresa Oliviera Lacerda suggests - are the subject of investigation for ethics and should be considered (!) in the context of moral education (Lacerda, 2012, p. 237). (As a person dealing with aesthetics and aesthetic education, she does not acknowledge that they should be considered (!) first, or also, from the perspective of the aesthetics of ugliness seen as providing contrast for comparison to what is beautiful.) 
A certain group of lecturers and instructors at public academies of physical education in Poland has been endeavoring to level the position of an academic teacher dealing with a specific sports discipline who is at the same time an experienced coach and whose students have achieved outstanding success (world/continental/Olympic records and trophies) with the status of an accomplished artist who is at the same time a lecturer at an art college and whose students have not only distinguished themselves among other students but also became successful to a lesser or greater extent in their professional career.

The group of teachers mentioned above consists mainly of people employed at institutes, departments, and faculties specializing in theory and practice of sport, who focus on their teaching and coaching activity more than they focus on research. They have been soliciting exemptions from research duties of standard academic researchers and teachers. Instead, they wanted to be treated the same as the full-time staff who teach art degree courses (theater, film, music, fine arts). They have proposed that their teaching effects should be accounted for in the same way they are at art colleges, which means they should be based on the didactic results of coaching (where coaches are misidentified with artists) and the possible successes of their students.

They did not consider the fact that the abilities acquired, the effect of coaching, and the possible successes of a student-athlete do not proclaim a particular coach to be artist of any kind. Just as a student of any academy of physical education and sport does not receive any artistic education, so his academic teacher-coach does not have anything in common with that type of education, as the pedagogical means and responses to them pertain to education connected with the study of sport or, more broadly speaking, of physical culture. Here, no artistic values infiltrate course outlines and teaching contents of the academies in question. An attempt to equate sports coaching with any artistic profession is an apparent formal and substantive error. What in a way connects the two is the general assumption about higher education: namely, that its aim is to teach a profession and broaden one's general and specialist knowledge. What decides the character of a given college and the education of its alumni and alumnae is, above all, the specialist knowledge connected with the college's profile. Therefore, it could be said that physical education teachers and coaches with university degrees are as close to artistic professionals as lawyers, economists, dentists, firefighters, and graduates of police and military academies.

Coaching skills - even those involving creative guidance of young or mature athletes inspiring them to extraordinary, even supernatural achievements - cannot, either formally or substantively, be described as artistic talent, and their effects deemed artistic achievements in any artistic discipline.

\section{The aesthetics of ugliness in art and sport}

One can come across similar aesthetic terms applied to describe a sports event and various art forms. Yet, however close they may sound, their content is dissimilar: this affinity is true for terms used to discuss beauty, ugliness, the drama/tragedy/comedy of the moment, an aesthetic experience, etc. All these emotional experiences are connected with the game, with striving for success while playing by the rules and regulations that do not contain any postulates that would make an artistic effect their primary aim. All the dramatic, tragic, and comic occurrences result from, are inspired by, and connected with the typical characteristics of a game, a sports event that does not attempt to above all expose either formal or aesthetic premises of any art. It does not mean, however, that - as David Best claims - sports activity is not at all an aesthetic phenomenon (Best, 1980, pp. 69-80; Kreft, 2012, p. 225).

The aesthetics that prevail at sports events are that of the everyday (see: Kreft, 2012, pp. 220-224; Mandoki, 2007; Saito, 2007; Welsch, 2005, pp. 135-155; Wright, 2003, pp. 83-92), the real, and the useful ${ }^{7}$.

\footnotetext{
${ }^{7}$ Lev Kreft holds the opinion that "to develop aesthetics of sport, we should not begin with aesthetics as philosophy of art but with aesthetics of everyday life" (Kreft, 2012, p. 219). Similar to the eminent philosopher and professor of aesthetics at the University of Ljubljana, I believe that aesthetic phenomena connected with sport should be considered from the perspective of the aesthetics of everyday life and not the aesthetics seen as part of the philosophy of art. They should, however, be also considered in the light of the aesthetics of reality and practical aesthetics. For instance, the
} 
It involves what is commonly and discretionarily, subjectively and corporately, intuitively and through indoctrination, considered beautiful in the conventional sense. In such a case we are dealing with axiotics, that is, the sensory reception and mental perception of beauty without the axiological, theoretical, or philosophical context (Kosiewicz, 2004).

The first of the aforementioned forms of aesthetics concerns: attractive hairdos and makeup; colorful nails; tastefully designed and eye-catching costumes and sports equipment; as well as posters, banners, and other forms of advertising placed on the site of a sporting event.

The second form, in turn - connected with the aesthetics of reality - regards the beautiful faces and bodies; the shapely, muscular build of the competitors; the beautiful, purebred animals, e.g., dogs and horses; it also regards the breathtaking ski runs in alpine and cross-country skiing, and the water bodies used for sailing, rowing and canoe regattas.

The third is connected with the beautifully and functionally prepared indoor and outdoor sports venues.

The kinds of aesthetics mentioned above can usually be observed at sports events in a mixed form.

A crucial component of the aesthetic characteristics of sports disciplines, rivalry, competitions and sporting spectacles is ugliness. The aesthetics of ugliness in sport emerges in two forms:

a) the pre-planned and pre-prepared

and

b) the aleatoric, that is, random or possible to appear although it is not sure whether it will appear at all, and if it does, what form it will assume (Kosiewicz, 2010, pp. 277-283).

The first one is chiefly connected with the introduction of elements such as makeup (face painting), choreographic messages, and aggressive behavior that lift supporters' spirits but can also negatively affect the opponents, scaring them and diminishing their will to fight.

The following may serve as examples:

a) Black teeth protectors/mouth guards worn by martial arts competitors who part their lips in a sinister, devilish smile to intimidate the opponent;

b) Specially tousled hairstyles, bizarre makeup, and face paintings that appear, for instance, between the eyes on the faces of New Zealand rugby players or some wrestlers, and that resemble the menacing, threatening warpaint of Native Americans, Aboriginal Australians, and the Maori of New Zealand (see: Pawlik, 2010, p. 62; Pawlik, 2011, pp. 111-116). One can catch a glimpse of similar paintings under the helmets of American football players;

c) Ritualistic, dynamic and frightening show modeled on the traditional Maori war dance that spelled crashing defeat of the opposing team, presented by the New Zealand rugby team before the game begins;

aesthetics of reality connected with rowing regattas or cross-country runs is not a display of everyday aesthetics for the spectator. It is part of the aesthetics of everyday for the rowers and runners, as well as people dealing with them professionally, just as the process of painting or sculpting is what certain artists do on a daily basis.

Some indoor and outdoor sports venues are connected with the aesthetics of everyday life. For instance, the beautifully designed ice rinks for hockey games that are also made available for recreational skaters. This, however, does not apply to F1 circuits, bobsleigh and sleigh tracks, whitewater kayaking routes, cross-country tracks for versatile horseback races, ski jumps, venues for track and field events. Even the possibly frequent viewing of live sports events or their broadcasts does not change the formal status of those events connected with practical aesthetics because it does not turn them into manifestations of the aesthetics of every day. This also applies to the works of art seen in museums, cinemas or theaters. The great number of viewers and popularization through different media does not change the artistic status of those works or make them manifest the aesthetics of every day. This regards the popularity of eminent works of prose and poetry (e.g., works by the Nobel Prize laureates) among readers. 
d) The blustering, nerve-racking gestures and horrid behavior of boxers at press conferences and during the tests or the weigh-in ceremony. Boxers very often provoke one another in a defiant and crude way: they spit, intimidate, throw insults at, push, and punch one another unawares.

The last example shows repulsive, particularly bad behavior, in both an aesthetic and colloquial sense. It is, however, accepted and often exhibited despite the awful aesthetic taste of the initiators and the performers of the provocation. It constitutes a well thought-out and cleverly prepared "horrid show," like that in wrestling ${ }^{8}$; it is no accident that there are journalists and TV cameras to witness that. The interest in the clash, in the possibly dramatic brawl and perhaps tragic consequences prompted by the deep and mutual (whether real or fake) resentment manifested earlier, increases. This attracts more spectators in the sports hall and increases the number of people willing to pay to access premium sports channels, together with the offer and price of TV commercials. It should be noted that this "horrid and dreadful show" and the shocking (although staged) excesses are rarely subject to criminal, civil, or administrative penalties. The alleged victims usually do not claim compensation for the injuries sustained.

The second, or unplanned, form of the aesthetics of ugliness possesses a natural rather than artificial resonance. It causes spontaneous reactions: repulsion, disgust, compassion, pity, and dismay. Despite all that, the spectators do not stop watching the show. Similar to the previous one, this form of aesthetics also fulfills their expectations.

The butchered faces of boxers, deformed by swelling, lumps, bruises; cut skin, smashed noses; dripping blood, deformed ears of wrestlers, pot-bellied sumo wrestlers; freakish frames and twisted muscles of body builders, male and female; sweaty, dirty outfits, bodies and faces of speedway riders; staggering, fainting female contenders; faces contorted with pain after injuries, intentional, brutal fouls and bites; frostbitten arms, legs, ears and noses of Himalayan mountaineers - all bears spectacular testimony to the aesthetics of ugliness aleatorically interwoven with sports rivalry. None of this evokes associations with the aesthetic and artistic qualities of art. It is connected with the risks of practicing a given sports discipline.

The injuries increase interest in sport and its spectacular and tragic aspects witnessed live. Ever since Roman times, the injuries have attracted a specific audience of spectators fascinated by fierce fight, dirt, sweat and tears, injuries, suffering, the sight of blood, and death. The aesthetics of ugliness and passion for its radical and extreme forms is rooted deep in human nature. Modern spectator, professional, or Olympic sport surely satisfies the emotional needs of this aesthetics, spectacularly presenting the ontological, aesthetic, axiological, praxeological and moral aspects of evil. The extreme forms of evil characteristic of the aesthetics of ugliness connected with sport will generate more and more sports media interest.

In art, the aesthetics of ugliness shows itself differently; the autotelic aesthetic and artistic conventions underlie it. For instance, it applies to poetic turpism present in the works of Rafał Wojaczek. His output (four collections of poems) is characterized by an obsession with ugliness, shockingly drastic language and imagery brimming with physiological and sexual connotations. The more benign variety of turpism can be found in the works of Miron Białoszewski, e.g., in his book of poems titled Obroty rzeczy (The Revolution of Things): it relates to the everyday life and objects. The aesthetics of ugliness is designedly (not incidentally)

\footnotetext{
${ }^{8}$ It should be noted that in a professional wrestling match, which is a staged spectacle of para-sport and para-wrestling character, the worst (the ugliest, aesthetically speaking) technical and tactical solutions are desirable and anticipated by the spectators: the more 'brutal' they are, the more they infringe the rules of fair play, honesty, trust and integrity, the better. The wrestlers kick hard, dig with elbows, crush throats, jump down from ropes, jump on the lying opponents, finish off the staggering, shattered contestants, and treacherously throw them out of the ring, straight onto tables and chairs of the "referees," and on the audience. Everything is allowed, anything goes: the more hideous, surprising and shocking, the more likely it is to win the applause of the "fans" and make them happy.
} 
incorporated into the artistic structure as an essential component of art that also tells -in the case of both Wojaczek and Białoszewski - of great and sublime poetic craftsmanship.

Shocking the recipients with terrifying or repugnant forms of ugliness may result in a surprisingly intense, virtually seismic artistic and aesthetic effect, just as in The Kindly Ones, the more than 1,000-page prose masterpiece by Jonathan Littell (the novel was awarded the Prix Goncourt in 2006). It contains macabre passages that are extremely sophisticated in terms of language and depict various mass killings, including those carried out by the Nazis during their invasion of the Soviet Union.

In feature films and theater performances, employing various, even terrifying, forms of ugliness is, among other things (and similar to poetry and prose), a technical aesthetic measure activating specific content and form. All the brutal scenes are artificial: mutilations, wounds, hara-kiri, battering and executions of prisoners of war; limbs torn out, heads cut off, gushing blood; death in a car crash; fainting fits and frostbite. They appear in an imaginary world, beyond reality; they expose the imagination of the creator; for instance, the screenwriter and the director, who work together consciously employing turpism to achieve their design - what they see as the optimum goal. Therefore, the ugliness, the macabre and repulsive scenes are not a side effect, something subsidiary and aleatoric like in sport, but a deliberate result preceded by multiple repetitions (on the film set) or theater rehearsals that can extend over many months. They are immanent, cohesive, and indispensable elements of a given work of art.

People watching a feature film in the cinema, on TV, online, or on mobile devices know that it was based on a more or less refined screenplay. In American cinema, for instance, a screenplay tends to be very precise, and is repeatedly altered and corrected. French and Italian New Wave cinema, in turn, very often contain only an outline of the plot and allows for improvisation on set, like in Federico Fellini's " $81 / 2$ " with Marcello Mastoriani cast in the role of the director.

The audience knows that they are not watching a documentary or a report relating real-life events, but a work of art, an artistic creation. The more accurate and convincing a feature film is in presenting interpersonal relationships and characters' behavior in various contexts (social, cultural, civilizational, religious, political, ideological, urban, rural, and solitary), the greater the emotional impact on the audience, the deeper the affection and the aesthetic experience. However, when the film is over, the audience knows they are dealing with fiction and that they have to return to actual, authentic, and non-cinematic social relationships.

The theater audience, in turn, knows that they are dealing with art and that everything that happens on stage is not real. They consciously accept the convention of "the magic curtain" or "the fourth wall" characteristic of a classic picture frame stage: that is, a curtain and a wall which do not block the view but reveal to the audience what is happening on stage while supposedly keeping it secret from the characters who, as though unwatched, create "real" and believable, closely private relationships.

Spectators at sports events, on the other hand, are dealing with real - not fictional - athletic events, with genuine rivalry, sometimes even with life-threatening situations. They may be at an event in person, as members of the audience. Moreover, they may also observe and comment on the course of events either in real time or post factum, through e-media (TV, computers, mobile phones), documentaries, reports or press coverage.

The physical exertion, fouls, bitter struggles, injuries, celebration of victory (as well as the changing behavior and various reactions of fans) pertain to authentic, non-fictional and non-artistic situations, individuals and teams in pursuit of praxeological goals that above all assume optimum effectiveness.

\section{Sports and theater spectacle versus other audio-visual (AV) forms}

A sports show, or spectacle, is very often compared to a theater show, or spectacle, and never to a film screening or any other audio-visual (AV) form (Lewicki, 1964), also called screen phenomena. However, those other AV forms are present at sports events and fill the huge, often enormous screens with various 
content served in various forms. Skillfully integrated into its functional structure, they have become a permanent and substantial part of a sports spectacle. They reinforce its message and emotional context. Presentations of individual contestants and competing teams, their greatest achievements, instant replays of the most interesting or crucial fragments of the game, as well as eye-catching advertisements displayed on screen are very dynamic, expressive, colorful and pleasing to the eye.

Their target is primarily practical, not artistic. The AV materials are prepared with the best use of editing techniques (for instance, soft and, in particular, hard cuts) that go back to the beginnings of cinematography and are now used also in the making of other AV materials presented on screen. Their aestheticization is becoming more and more prominent: AV media in sport not only provide information, but also make viewing sports events more pleasurable, encourage participation in consecutive events (either in person or through e-media), and stimulate increase in viewership. All this commercializes sport and increases profit from the event and the featured commercials. This in turn helps generate more interest in sport and boosts the advancement of sport, both active and passive, competitive (professional, Olympic, spectator) and leisure, the latter more broadly seen as sport for all, mass sport or universal sport (Kosiewicz, 2010, pp. 21-22).

Therefore, AV media perform a very important, although subordinate, function in sports spectacle. AV media do not constitute the main goal or have primary value for the spectacle. They are an additional element that facilitates the event's reception and also assists with the practical and emotional aspects of the rivalry.

A sports spectacle is never compared in terms of form or performance to film, or any other AV forms. It is chiefly compared to stage and theatrical performance, even though sport is neither theater nor any other art form. Yet there are real people, people in the flesh, both in a sport and a theater spectacle. However, they perform entirely different, virtually non-comparable social roles there. In the case of sport, the main objective is to achieve the highest possible score and rank in a given discipline subject to specific regulations; in the case of theater, the objective is to achieve the greatest artistic effect possible, the greatest success in a specific artistic discipline. But sport disciplines are not treated as artistic disciplines simply because they are controlled by different ministries.

In AV media, in turn, only substitutes of real-life actors and sportsmen can be seen, even if the technology is three-dimensional. What the viewer can see is not actual psycho-physical reality, a living organism, a functional human structure; it is only a shadow or a superficial multicolor two- or threedimensional gleam, a reflection, a transmission of a mirror image. A real human being cannot be present in two different places at the same time: at a sports arena or theatrical stage, and in transmission - on screen.

Even AV media providing live coverage of events in real time on big wall screens placed at the venue of the event transmitted are no an exception to the above-mentioned rule. In such cases, the spectator may decide to either directly follow the action as it takes place on a pitch, a pit or a rink, or do it indirectly, in close-up, on screen. However, the screens - regardless of the AV form - show only the images of rivals, not the real contenders: the more or less dynamic athletes in motion.

It should be noted that AV media have become popular in theater as well. Nowadays, they have already penetrated and are fully assimilated - despite their distinct genre-related provenance - into its generic core. They have become an immanent part of the theatrical alphabet, the language of theater. Among others, it is true for the avant-garde productions of the most talented and internationally acclaimed Polish theater directors (and managers) in their 40s and 50s, such as the Warsaw-based artistic giants Grzegorz Jarzyna (G.J.) and Krzysztof Warlikowski (K.W.), and their outstanding productions titled The Bat (G.J., staged in Teatr Rozmaitości in Warsaw, among other places) as well as (A)pollonia and Warsaw Cabaret (K.W., staged in Warsaw's Nowy Teatr, among other places). The AV forms used in those productions (fragments of films and TV programs displayed on canvas or electronic screens) expand, deepen and enrich the narration, the aesthetics, and the artistic impact of even the classical, traditional theater dramas. Some actors show close-ups of themselves or actions of other characters using small cameras (e.g., Dawid Ogrodnik in The Bat). Professional cameramen are also employed. Their filmed and screened silhouettes, the 
moving pictures cast into stage space, reinforce the spectacle's expressiveness; and sometimes they simply facilitate its reception. Such is the case of Krzysztof Warlikowski's (A)pollonia, produced on an enormously wide stage with broken rows of almost 100 chairs. A member of audience seated at one of the extreme ends of the stage can closely observe the action unraveling at the other end only by dint of screen transfer.

$\mathrm{AV}$ material has become an aesthetically and artistically cohesive and an essential component in many theatrical productions. In a sports spectacle, on the other hand, what is displayed on screen is only subsidiary; it facilitates and boosts the spectator (practical, informative, emotional) message. Sports competitions took place before it was invented, and can still take place without it. AV material is not an immanent, indispensable, and necessary part of generic nature of any real (not artificial) sports rivalry. The various virtual (computerized) forms of sports activity that bear resemblance to real-life rivalry that are widely popular today constitute an exception to this concept.

\section{Summary}

In this paper, I have endeavored to question the popular, evaluative beliefs of those sport aficionados who strive hard to elevate the formal, functional and axiological status of sport, an attempt surely made in good faith. Some of them attribute to sport an extraordinary moral mission, a mission of a prescriptive character, a mission connected with propagating the intuitively understood goodness. Others, in turn, try to convince others that competitive sport is also a form of art and should also be analyzed and evaluated from the perspective of qualities, categories and criteria characteristic for art and artistry, and these should be as crucial as the praxeological values of sport (see: Ossowska, 1946). The attempt to relate sport to art by finding the properties shared by the two is a yet another attempt at trying to prove that sport is something more than just sport (which was true in Ancient Greece, where the Olympic Games were not only an occasion for athletic rivalry, but also constituted a form of religious worship, contained soteriological messages, and conveyed a code of ethics of the now lost culture and religion).

In this paper, I focused on describing what I believe to be the main differences between sport and art. In the article on which I am currently working, I shall attempt to show that a close relationship between sport and art does not exist even where it is commonly believed that the two display an affinity or converge.

\section{REFERENCES}

Best, D. (1980). Art and sport. Journal of Aesthetic Education, 2, 69-80.

Best, D. (1988). Sport is not art. In W.I. Morgan \& K.V. Meier (Eds.), Philosophic inquiry in sport (pp. 527-539). Champaign, IL: Human Kinetics.

Coakley, J. \& Dunning, E. (2000). Handbook of Sport Studies. London: Sage.

Dunning, E. (2002). Figurational Contributions to the Sociological Study of Sport. In Maguire \& K. Yung K. (Eds.), Theory, Sport \& Society, London: Jai.

Elcombe, T.L. (2012). Sport, Aesthetic Experience, and Art as the Ideal Embodied Metaphor. Journal of the Philosophy of Sport, 2, 201-217.

Elias, N. \& Dunning, E. (1986). Quest for Excitement: Sport and Leisure in the Civilizing Process. Oxford: Basil Blackwell.

Eichberg, H. (1998). Body Culture. Essays on Sport, Space and Identity. London: Routledge.

Eichberg, H. (2009a). Body Culture. In S.W. Pope \& J. Nauright (Eds.), The Routledge Companion to Sport History. London: Routledge.

Eichberg, H. (2009b). Body Culture. Physical Culture and Sport. Studies and Research, XLVI, 79-98.

Godlewski, P. (2005). Kultura fizyczna - termin i system na usługach marksistowskiej ideologii (Physical Culture: A Term and a System Serving Marxist Ideology). In Dziubiński, Z. (Ed.), Sport jako kulturowa rzeczywistość (Sport as a Cultural Reality). Warsaw: Wydawnictwo Poligrafia Inspektoratu Towarzystwa Salezjańskiego. 
Gołaszewska, M. (1984). Estetyka rzeczywistości (The Aesthetics of Reality). Warsaw: Instytut wydawniczy PAX. Guttmann, A. (2004). From Ritual to Record: The Nature of Modern Sport. New York, NY: Columbia University Press. Hegel, G.W.F. (1963). Fenomenologia ducha (The Phenomenology of Spirit). T. 1. Warszawa: PWN, pp. $216-228$.

Huizinga, J. (1995). The Nature of Play. In W.I. Morgan \& K.V. Meier (Eds.) Philosophic Inquiry in Sport. Champaign, IL: Human Kinetics.

Kosiewicz, J. (2010). Social and Biological Context of Physical culture and Sport. Physical Culture and Sport. Studies and Research, 5-31. DOI: 10.24780v 10141-10-0021-1

Kosiewicz, J. (2004a). Filozoficzne aspekty kultury fizycznej i sportu (Philosophical Aspects of Physical Culture and Sport). Warszawa: Wydawnictwo "BK".

Kosiewicz, J. (2004b). The Universals of Sport - from Realism to Nominalism. In D. Macura \& M. Hosta (Eds.), Philosophy of Sport and Other Essays. Ljubljana: Faculty of Sport, University of Ljubljana.

Kosiewicz, J. (2010). The Sporting Spectacle from the Point of View of Aleatorism. In Sport and Philosophy: From Methodology to Ethics (pp. 277-283). Warsaw: Wydawnictwo BK.

Kreft, L. (2012). Sport and Drama. Journal of the Philosophy of Sport, 219-234.

Kreft, L. (2012). Sport and Aesthetics of Everyday life. In Sport and Drama. Journal of the Philosophy of Sport, 220224.

Kretchmar, R.S. (2008). Games Came from "Nowhere" and "Somewhere"... at the Same Time. Studia Humanistyczne (Humanistic Studies), 8. Str. 43-49

Kretchmar, R.S. (2009). Do Games Require Artificial Problems that are Neither Too Hard Nor Too Easy? (Conference transcript) International Association for the Philosophy of Sport Conference Presentation, Seattle Washington, August 2009.

Kotarbiński, T. (1982). Traktat o dobrej robocie (Praxiology. An introduction to the science of efficient action). Wrocław: Zakład Narodowy im. Ossolińskich Wydawnictwo PWN.

Lacerda, T.O. (2012). Education for the Aesthetics of Sport in Higher Education in the Sports Sciences - The Particular Case of the Portuguese-Speaking Countries. Journal of the Philosophy of Sport, 235-250.

Lewicki, B.W. (1964). Wprowadzenie do wiedzy o filmie (An Introduction to Film Studies). Wrocław-WarszawaKraków: Wydawnictwo Ossolineum.

Mandoki, K. (2007). Everyday Aesthetics: Prosaics, the Play of Culture and Social Identities. Hampshire and Burlington: Ashgate.

Malcolm, D. (2008). Introduction. In Malcolm, D. (Ed.), The Sage Dictionary of Sport Studies (pp. XI-XIV). Los Angeles-London-New Delhi-Singapore: Sage.

Melo, V.A., Monteiro, M., Peres, F., Preira, C., Campos, L., Silva, M., at al. (2007). O Projecto « Esporte e Arte: Dialogos »: A Construcao de um Banco de Dados. Pensar a Pratica 10, 2, 337-355.

McPherson, B.D., Curtis, J.E. \& Loy, J.W. (1989). Defining Sport. In B.D. McPherson \& J.E. Curtis (Eds.), The Social Significance of Sport. Champaign, IL: Human Kinetics.

Meier, K.V. (1995). Triad Trickery: Playing with Sport and Games. In W.I. Morgan \& K.V. Meier (Eds.) Philosophic Inquiry in Sport. Champaign, IL: Human Kinetics.

Moller, V. (2003). What is sport: Outline to a Redefinition. In V. Moeller \& J. Nauright (Eds.), The Essence of Sport. Odense: University Press of Southern Denmark.

Myśliwski, W. (2013). Ostatnie rozdanie (The Final Draw), Warszawa: Wydawnictwo Znak.

Ossowska, M. (1946). O dwóch rodzajach ocen (On two kinds of evaluation). Kwartalnik Filozoficzny, (Philosophical Quarterly).

Pawlik, D. (2010). Rytualne zdobienia ciała Maorysów. Sztuka Ta-moko (Maori ritual body embellishments. The art of Ta moko). Antypody, 2, 56-61.

Pawlik, D. (2011). Maori ritual body embellishments. IDO Movement for Culture, 11, 111-116.

Plato (2012). Phaedru. In C.D.C. Reeve (Ed.), A Plato Reader. Eight essential dialogues. Indianapolis: Hackett, pp. 213-226.

Plato (20120. Symposium. In C.D.C. Reeve (Ed.), A Plato Reader. Eight essential dialogues. Indianapolis: Hackett, pp. 157-208. 
Saito, Y. (2007). Everyday Aesthetics. Oxford: Oxford University Press.

Schmid S. (2009) Reconsidering Autotelic Play. Journal of the Philosophy of Sport, 2

Suits, B. (1995a). The Elements of Sports. In W.J. Morgan \& K.V. Meier (Eds.), Philosophic Inquiry in Sport. Champaign, IL: Human Kinetics.

Suits, B. (1995b). Tricky Triad: Play, Game and Sport. In W.I. Morgan \& K.V. Meier (Eds.), Philosophic Inquiry in Sport . Champaign, IL: Human Kinetics.

Tomc, G. (2008). The Nature of Sport. In M.D. Topic \& Licen S. (Eds.), Sport, Culture \& Society. Ljubljana: University of Ljubljana.

Welsch, W. (2005). Sport viewed aesthetically, and even as art? In A. Light \& J. M. Smith (Eds.), The aesthetics of everyday live (pp. 135-155). New York, NY: Columbia University.

Wertz, S. (1995b). Context and intention in sport and art. In W.I. Morgan \& K.V. Meier (Eds.) Philosophic Inquiry in Sport. Champaign, IL: Human Kinetics, pp. 29-41.

Wright, L. (1988). Aesthetic implicitness in sport and the role of aesthetic concepts. Journal of the Philosophy of Sport, 30, 83-92.

AUTHOR'S ADDRESS: $\quad$ Jerzy Kosiewicz

Department of Philosophy, Chair of the Social Sciences

Josef Pilsudski University of Physical Education in Warsaw

34 Marymoncka str., 00-968 Warsaw, Poland

Email: jerzy.kosiewicz@awf.edu.pl 